\title{
Turmeric and Ginger as Health Protective Food Sources - An Integrative Review
}

\author{
P.A.L. Jayathilake ${ }^{1}$, M. A. Jayasinghe ${ }^{1^{*}}$, J. Walpita ${ }^{2}$, K.P.R.I. Dilani ${ }^{2}$ \\ ${ }^{1}$ Department of Food Science and Technology, Faculty of Applied Sciences, University of Sri \\ Jayewardenepura, Gangodawila, Nugegoda, Sri Lanka. \\ ${ }^{2}$ Instrument Centre, Faculty of Applied Sciences, University of Sri Jayewardenepura, \\ Gangodawila, Nugegoda, Sri Lanka.
}

Date Received: 24-10-2021 Date Accepted: 17-12-2021

\begin{abstract}
Most of the medicinal plants utilized in traditional medicine are spices. Majority of those spices are widely used for aroma, flavour and colour in cuisine though they behave as appetizers, digestives, preventives and aphrodisiacs. Turmeric (Curcuma longa) and ginger (Zingiber officinale) are classic examples for such spices which are also considered as herbal plants having antioxidant, anti-microbial and anti-inflammatory properties. Their antimicrobial properties are in a broad spectrum that provides a considerable immunity development within the human body. This review summarizes the beneficial characteristics of major active constituents in turmeric and ginger and their presumed pharmacological potential to safeguard human health.

Keywords: Turmeric, Ginger, Curcumin, Human health, Active Ingredients, Nanotechnology

\section{Introduction}

From the ancestral time to date, lots of plants have been used for medicinal purposes. The uses of traditional medicine have now been realized as the new trend, since it is believed that the natural drugs are safer and may demonstrate synergistic effects (Mekuriya and Mekibib, 2018; Hossain, Hoque and Nasrinsultana, 2020). Only traditional medicine was used as remedies to cure both acute and chronic diseases (Mekuriya and Mekibib, 2018), until the beginning of $19^{\text {th }}$ century. Traditional medicine in a country is based on simple to use, easy to access plants, mostly become popular through indigenous knowledge. Most of the traditional medicinal plants, are used as spices, especially in eastern cuisine (Kizhakkayil and Sasikumar, 2011; Arutselvi et al., 2012). Despite the great role of those herbal plants as spices, they pacify the human health via various mechanisms (Tassou, 2006).

Even though spices are mostly used in cuisines for aroma, flavour and colour, the utmost purpose of using them could be as appetizers, digestives, preventives and aphrodisiacs (Tassou, 2006; Hossain, Hoque and Nasrinsultana, 2020). During the most of the global pandemic situations, humans behold about the traditional medicine, medicinal plants and herbal plants which could be used as spices. Moreover, due to the drug resistance infections of commonly used antibiotics and many other drugs, there is an increased interest to search for new or alternative compounds derived from natural herbal plants and spices.
\end{abstract}

*Correspondence: madhura@sci.sjp.ac.lk

Tel: +94716255690

(C) University of Sri Jayewardenepura 
Both Curcuma longa (Turmeric) and Zingiber officinale (Ginger) are from Zingiberaceae family, which have been rampant and frequently used as spices in cuisines or as traditional medicine. Turmeric is a frequently used spice worldwide and a perennial crop which has short stem. It has ovate, oblong or pyriform shaped rhizomes that are usually branched. Turmeric rhizomes are typically brownish yellow. It has been utilized as an ayurvedic medicine for centuries in Asia. This native spice of the South - East Asian region, has been typically used as a colorant, a flavouring additive and a preservative (Rathaur et al., 2012). The dried powder of C. longa rhizome have shown anti-microbial, anti-parasitic, antiinflammatory, antioxidant and anti-cancer activities (Negi et al., 1999; Guerra et al., 2020). Curcuminoids are the major constituents; yellow colour pigments of turmeric rhizome powder (Negi et al., 1999). Curcumin along with demethoxycurcumin (DMC) and bisdemethoxycurcumin (BDMC) are major curcuminoids of the turmeric oleoresin (Revathy et al., 2011). A work from Chowdary and co-workers revealed that ar-turmerone, turmerone, and curlone are also available in turmeric as major compounds along with other oxygenated compounds (Chowdhury et al., 2000).

On the other hand, Z. officinale alias Ginger is an herbaceous perennial and a tropical monocotyledonous plant, the rhizome of which is used as a spice. It typically grows to a height of $1.25 \mathrm{~m}$ and is grown in tropical climates (Suruchi et al., 2016). Recently, a wide span of biological activities have been identified in Ginger such as anti-inflammatory, anti-microbial, antioxidant and analgesic actions, anti-parasitic effects, gastro-protective effect, cholesterol-lowering or lipolysis-lowering properties, antitumour activity and anti-diabetic activity (Chang et al., 2013; Iotsor et al., 2019; Jeena et al., 2013).

Gingerol is the core constituent of ginger rhizome; meantime dehydrated form of gingerol, shogaol is the dominant compound in dried ginger. A thermally labile zingiberene fraction can be obtained from a diethyl ether extract of ginger oleoresin. The essential oil of ginger consists of zingiberene, curcumene, camphene, beta-phellandrene, cineole, terphineol, terpenes, borneol, geraniol, geranyl acetate, limonene, linalool, beta-bisabolene, alpha- farmesene and alpha- beta-sesquiphellandrene, (Chrubasik et al., 2006)(Iotsor et al., 2019). Ginger oleoresin isolated using acetone or ethanol mainly consists of gingerol, shogaol, zingerone, paradol, zingiberol, zingiberene, gingediol, diarylhepatanoids, vitamins and phytosterols (Zadeh and Kor, 2014).

Recently, nanotechnology provided a novel template for innovations in food industry. Many studies have been carried out to address major issues in value added products of natural products such as low thermal stability, and poor bioavailability due to low water solubility. In particular, the limited water solubility of curcumin and its derivatives have been studied using various nano-templates such as nanoclays, layered double hydroxides, liposomes chitosan, and hydroxyl apatite (Chrubasik et al., 2006). For example, nanoliposomes (TEL) incorporated with turmeric extracts and their potential applications in beverages as functional foods were investigated. The TEL has indicated higher antibacterial activities and higher antioxidant properties compared to the pure turmeric extract. Turmeric extract nano-emulsion powder (TE-NEP) was made by ultra-sonication and spray drying and then, was incorporated into milk to analyse the compatibility in a colloidal food, especially for treating gastric ulcers (Ali et al., 2008; Chrubasik et al, 2006).

Apart from the role of turmeric and ginger in traditional medicine and as spices, research work has been done to investigate their other functional characteristics. The aim of this comprehensive review is to compile many pharmacological health benefits of two spice plants of Zingiberaceae family, Turmeric and Ginger to safeguard human health. 


\section{Pharmacological activity of turmeric}

\subsection{Antibacterial activity}

Turmeric has shown antibacterial activity against several gram positive and negative bacteria. The growth of both gram positive and negative bacteria can be retarded with $20-90 \mu \mathrm{g} / \mathrm{mL}$ concentrations of turmeric extracts (Aly and Gumgumjee, 2011). Antibacterial activity of turmeric includes the hydrogen bonding as well as hydrophobic interaction between various phenolic compounds to membrane proteins that results in cell membrane disturbance, cell wall disruption and damage to electron transport chain in bacteria (Juglal et al., 2002). It has been proved that turmeric has an antibacterial activity against Clostridium septicum, Clostridium novyi, Clostridium sporogenes (Pope et al., 2004).

Mathanol and hexane extracts of turmeric have shown antibacterial activity against 13 types of bacterial strains including Aeromonas hydrophila, Vibrio cholera, Vibrio harveyi, Vibrio vulnificus, Vibrio parahaemolyticus, Vibrio alginolyticus, Bacillus cereus, Bacillus subtilis, , Staphylococcus epidermidis,Staphylococcus aureus, Streptococcus agalactiae, Staphylococcus intermedius and Edwardsiella tarda (Lawhavinit and Kongkathip, 2010). Through induction of filamentation, curcumin can suppress the Bacillus subtilis cytokinesis. Also, it significantly suppresses the cytokinetic $\mathrm{Z}-$ ring formation in Bacillus subtilis without affecting segregation and organization of the nucleoids significantly. It showed that curcumin can suppress the bacterial cell proliferation via inhibition of assembly dynamics of FtsZ (a prokaryotic homologue of eukaryotic cytoskeletal protein tubulin) in the $\mathrm{Z}-$ ring. This is reported as one of the possible antibacterial action mechanisms (Rai et al., 2008).

Some histamine-producing bacteria such as Vibrio parahaemolyticus, Pseudomonas aeruginosa, Bacillus cereus and Proteus mirabilis has been inhibited when turmeric extraction was incorporated at a concentration of 5\% (Paramasivam et al., 2007). The histamine producing bacteria Morganella morganii too can also be inhibited by turmeric (Shakila et al., 1996).

\subsection{Antifungal activity}

Turmeric oil can inhibit the growth of dermatophytes such as Microsporum gypseum, Epidermophyton floccosum, Trichophyton mentagrophytes, Trichophyton rubrum (Aplsarlyakul et al., 1995) and it has been shown antifungal activity against Aspergillus flavus, Aspergillus parasiticus, Fusarium moniliforme and Penicillium digitatum (Jayaprakasha et al., 2001). Ethanolic extract of turmeric has shown prominent antifungal properties against Trichophyton longifusus (Khattak et al., 2005). According to a study carries out by Kim and co-workers, the hexane extracted turmeric have elicited antifungal effect against Phytophthora infestans, Rhizoctonia solani and Erysiphe graminis with $1000 \mathrm{mg} / \mathrm{L}$ concentration (Kim et al., 2003).

Table 1: Minimum Inhibitory Concentration (MIC) values of some bacteria and fungi inhibited by turmeric

\begin{tabular}{clll}
\hline Bacteria / fungi & $\begin{array}{l}\text { Antimicrobial } \\
\text { substance }\end{array}$ & $\begin{array}{l}\text { Minimum } \\
\text { inhibitory } \\
\text { concentration } \\
\text { (MIC) }\end{array}$ & References \\
\hline Bacillus subtilis & Ethanol extract & $16 \mu \mathrm{g} / \mathrm{ml}$ & (Ungphaiboon et al., 2005)
\end{tabular}

*Correspondence: madhura@sci.sjp.ac.lk

Tel: +94716255690

(C) University of Sri Jayewardenepura 


\begin{tabular}{|c|c|c|c|}
\hline Staphylococcus aureus & Aqueous extract & $128 \mu \mathrm{g} / \mathrm{ml}$ & (Ungphaiboon et al., 2005) \\
\hline $\begin{array}{l}\text { Staphylococcus } \\
\text { epidermidis }\end{array}$ & Aqueous extract & $4 \mathrm{~g} / 1$ & (Niamsa and Sittiwet, 2009) \\
\hline Klebsiella pneumonia & Aqueous extract & $16 \mathrm{~g} / 1$ & $\begin{array}{l}\text { (Moghadamtousi et al., 2014; } \\
\text { Niamsa and Sittiwet, 2009) }\end{array}$ \\
\hline Escherichia coli & Aqueous extract & $4 \mathrm{~g} / 1$ & (Niamsa and Sittiwet, 2009) \\
\hline Helicobacter pylori & Methanol extract & $6.25-50 \mu \mathrm{g} / \mathrm{ml}$ & (Mahady et al., 2002) \\
\hline Methicillin-resistant & Curcumin & $125-250 \mu \mathrm{g} / \mathrm{ml}$ & (Mun et al., 2013) \\
\hline $\begin{array}{l}\text { Staphyloccous aureus } \\
\text { (MRSA) }\end{array}$ & & & \\
\hline Exophiala jeanselmei & Turmeric oil & $459.6 \mu \mathrm{g} / \mathrm{ml}$ & (Aplsarlyakul et al., 1995) \\
\hline Sporothrix schenckii & Turmeric oil & $114.9 \mu \mathrm{g} / \mathrm{ml}$ & (Aplsarlyakul et al., 1995) \\
\hline Fonsecaea pedrosoi & Turmeric oil & $459.6 \mu \mathrm{g} / \mathrm{ml}$ & (Aplsarlyakul et al., 1995) \\
\hline $\begin{array}{l}\text { Scedosporium } \\
\text { apiospermum }\end{array}$ & Turmeric oil & $114.9 \mu \mathrm{g} / \mathrm{ml}$ & (Aplsarlyakul et al., 1995) \\
\hline Candida albicans & Methanolic extract & $128 \mu \mathrm{g} / \mathrm{ml}$ & (Ungphaiboon et al., 2005) \\
\hline $\begin{array}{l}\text { Cryptococcus } \\
\text { neoformans }\end{array}$ & Methanolic extract & $256 \mu \mathrm{g} / \mathrm{ml}$ & (Ungphaiboon et al., 2005) \\
\hline Candida dubliniensis & Curcumin & $32 \mathrm{mg} / 1$ & (Martins et al., 2009) \\
\hline
\end{tabular}

\subsection{Antiviral activity}

Turmeric has shown antiviral activity against several viruses. Among active compounds of turmeric, one active component, curcumin (Figure 1) is proven to have high antiviral activities (Nisar et al., 2015). According to a study of different bio conjugates of curcumin, it has been proved that those bio conjugates of curcumin, namely, di- $O$-tryptophanylphenylalanine curcumin, di- $O$-pamitoyl curcumin, di$O$-decanoyl curcumin, $\mathrm{C}^{4}$-ethyl- $O-\gamma$-folyl curcumin, 4- $O$-ethyl- $O-\gamma$-folyl di- $O$-bis- $(\gamma, \gamma)$ folyl curcumin have potential antiviral effects against a variety of viral strains such as parainfluenza virus type 3 (PIV-3), vesicular stomatitis virus (VSV), feline infectious peritonitis virus (FIPV), flock house virus (FHV), herpes simplex virus type $1 \& 2$ (HSV) and respiratory syncytial virus (RSV).

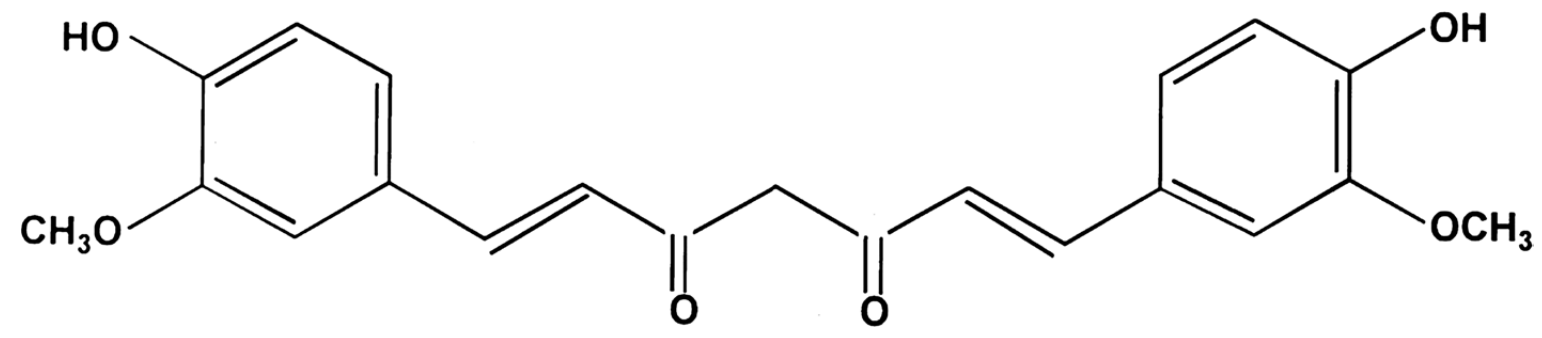

Figure 1. Curcumin: chemical structure

Furthermore, di-O-decanoyl curcumin and di-O tryptophanylphenylalanine curcumin has revealed remarkable antiviral activity against FIPV/FHV and VSV (Singh et al., 2010). Curcumin acts as an active 
inhibitor against Epstein - Barr virus (EBV) (Hergenhahn et al., 2002) and human immunodeficiency viruses PR8, H1N1, H6N1 (Kumari et al., 2015).

Table 2: Antiviral activity of turmeric

\begin{tabular}{|c|c|c|c|}
\hline Virus & Antiviral substance & $\begin{array}{l}\text { Mechanism of inhibition / } \\
\text { Mode of action }\end{array}$ & References \\
\hline HIV-1 & Curcumin & $\begin{array}{l}\text { Inhibit HIV-1 integrase } \\
\text { needed for viral replication }\end{array}$ & $\begin{array}{l}\text { (Mazumder et al., } \\
1995 \text { ) }\end{array}$ \\
\hline HIV-1 & Curcumin & $\begin{array}{l}\text { Inhibit HIV-1 LTR directed } \\
\text { gene expression }\end{array}$ & (Chiang et al., 1993) \\
\hline HIV-1 & $\begin{array}{l}\text { Curcumin, reduced } \\
\text { curcumin, allyl } \\
\text { curcumin and } \\
\text { tocopheryl - } \\
\text { curcumin }\end{array}$ & $\begin{array}{l}\text { inhibit Tat-mediated } \\
\text { transactivation of HIV-1 } \\
\text { LTR }\end{array}$ & $\begin{array}{l}\text { (Barthelemy et al., } \\
\text { 1998) }\end{array}$ \\
\hline Influenza & Curcumin & $\begin{array}{l}\text { Haemagglutination } \\
\text { Inhibition }\end{array}$ & (Chen et al., 2010) \\
\hline Coxsackievirus & Curcumin & $\begin{array}{l}\text { Inhibit virus replication } \\
\text { through dysregulating } \\
\text { ubiquitin proteasome system } \\
\text { (UPS) }\end{array}$ & (Si et al., 2007) \\
\hline Japanese encephalitis & Curcumin & $\begin{array}{l}\text { Reduce the production of } \\
\text { infective viral particles }\end{array}$ & (Dutta et al., 2009) \\
\hline HCV (Hepatitis C virus) & Curcumin & $\begin{array}{l}\text { Reduce viral replication by } \\
\text { subduing the Akt-SREBP-1 } \\
\text { pathway }\end{array}$ & (Kim et al., 2010) \\
\hline HBV (Hepatitis B virus) & Aqueous extract & $\begin{array}{l}\text { Reduce viral replication } \\
\text { through enhancing the level } \\
\text { of p53 protein }\end{array}$ & (Kim et al., 2009) \\
\hline
\end{tabular}

\subsection{Antiparasitic activity}

Some protozoan parasites are found to be inhibited by turmeric. The ethanolic extract of turmeric can inhibit Entamoeba histolytica. An in vitro study has shown curcumin can inhibit Leishmania. It is reported that curcumin can inhibit Plasmodium falciparum and Leishmania major (Koide et al., 2002). Several synthetic derivatives of curcumin inhibit Leishmania amazonensis (Gomes et al., 2002).

\subsection{Antioxidant activity}

Turmeric shows remarkable antioxidant properties compared to vitamin $\mathrm{C}$, vitamin $\mathrm{E}$ as well as $\beta$ - carotene. Free radical oxidation is associated with major chronic diseases such as cancer, atherosclerosis,

*Correspondence: madhura@sci.sjp.ac.lk

Tel: +94 716255690

(C) University of Sri Jayewardenepura 
cataracts, cardiovascular diseases and rheumatoid arthritis, it is believed that turmeric is good for above diseases (Mahakunakorn et al., 2003). Due to its phenolic nature, it alters serum glutathione and superperoxidase activity; reduces peroxidation of lipids and scavenges the reactive oxygen species (Navadagi, 2005). According to an in vitro study, curcumin can significantly inhibit the formation of reactive oxygen species such as superoxide $\mathrm{H}_{2} \mathrm{O}_{2}$, anions and nitrite radical formation by activated macrophages. It also has been proved in vivo that curcumin lowers the production of reactive oxygen species (Joe and Lokesh, 1994). When considering the effect of turmeric on nervous system, curcumin and manganese complex may provide protectio against vascular dementia by deploying the antioxidant activity (Thiyagarajan and Sharma, 2004). Further, turmeric acts as an excellent scavenger of free radicals by increasing the number of micronuclei in the circulating lymphocytes (Sachdeva et al., 2018).

\subsection{Anti-inflammatory activity}

Turmeric acts as an anti - inflammatory agent by lowering the histamine level, while increasing production of cortisone in adrenal glands. Also releasing of pro - inflammatory cytokine TNF $-\alpha$ and the gene which generate inflammatory COX -2 enzymes is greatly inhibited by turmeric (Rathaur et al., 2012).

\subsection{Anticancer activity}

Turmeric in particular its major active component curcumin, shows anti-carcinogenic properties too. Curcumin have inhibited proliferation of cells and piled up cells at G2/M cell cycle (Sharma et al., 2005). According to a study done on oral cancer, it is mentioned that curcumin taken either with diet or applied locally have the ability to greatly reduce DNA adducts (Krishnaswamy et al., 1998).

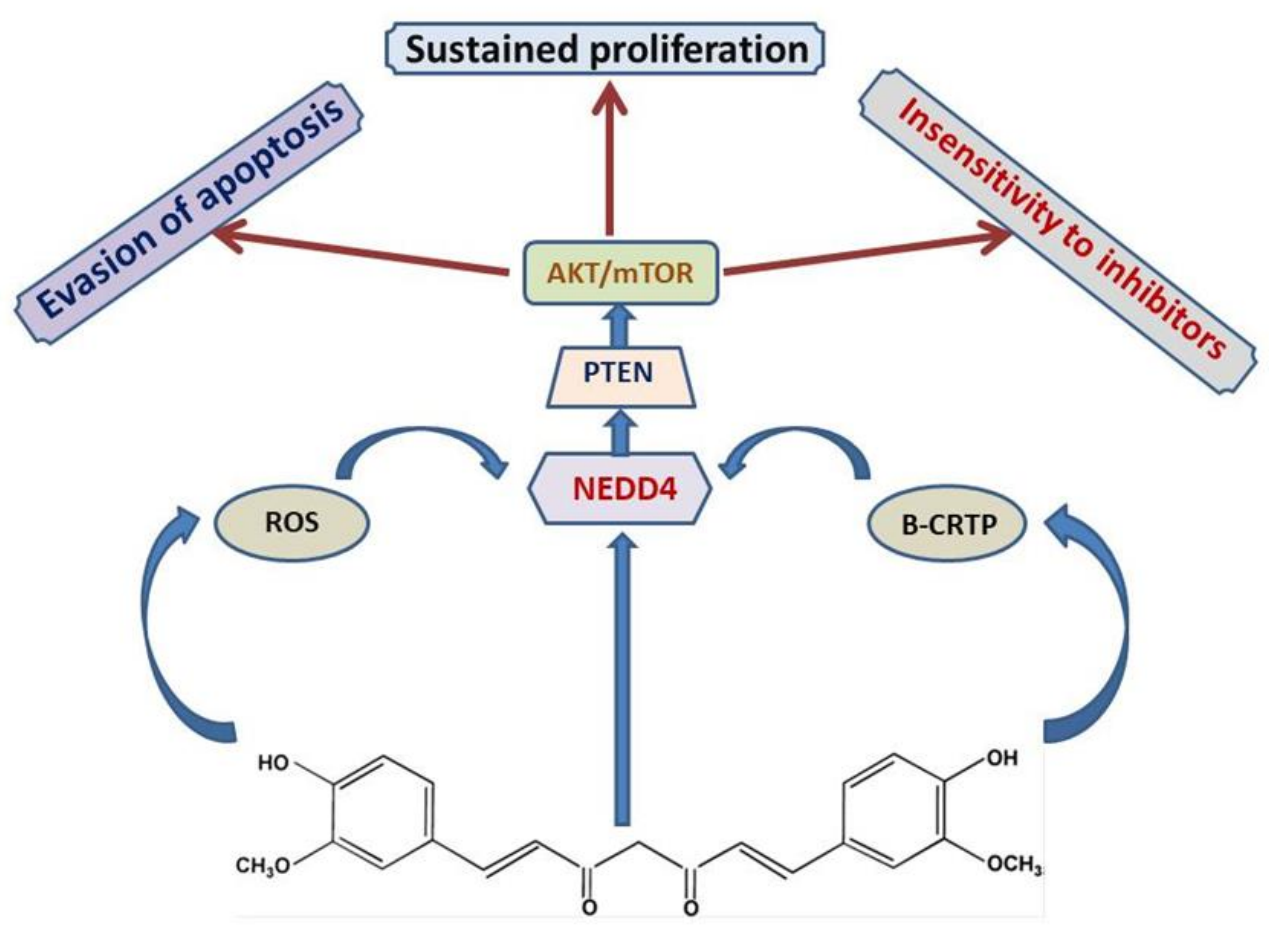

Figure 2. Multiple active mechanisms of curcumin against cancer 
Curcumin has been shown to act in different ways to avoid cancers by targeting the distinctive features of cancer like sustained proliferation, sustained angiogenesis, evasion of apoptosis, tissue invasion, insensitivity to growth inhibitors and metastasis etc. (Figure 2). In addition, curcumin targets the avoidance of immune system by tumors and aids to restore immune activity, supressing the growth of cancer. Curcumin interferes several processes like restoration of CD4+/ CD8+ T cell populations, decrease of Treg cell population, reversal of type-2 cytokine bias and suppression of $\mathrm{T}$ cell Apoptosis which facilitate to resurrect tumor immune surveillance that direct towards tumor regression (Bose et al., 2015).

\subsection{Other health benefits}

Turmeric is used in numerous medicinal applications in atherosclerosis, anaemia, diabetics, haemorrhoids, oedema, hysteria, hepatitis, indigestion, skin diseases, inflammation, urinary diseases, psoriasis, wound and bruise healing, cough, anorexia, rheumatism, sinusitis and liver disorders (Chattopadhyay et al., 2004). Turmeric is considered to be an excellent remedy for skin diseases such as acne, eczema and skin cancers due to its antibacterial and antiseptic properties and also it prevents premature ageing (Phan et al., 2001). Researchers show that turmeric powder can be applied in treatments for sputum, ear and eye pains, sinusitis, toothaches and dyspnoea (Suryanarayana et al., 2003).

On the other hand it has been reported that turmeric prevents heart diseases by lowering cholesterol in blood and by preventing blood clot formations that leads to heart attacks and strokes. It is believed that the activity is due to the inhibition of platelets aggregation by turmeric through potentiation of prostacyclin synthesis and inhibition of thrombin synthesis (Chan et al., 2006). Turmeric is good for controlling body cholesterol as curcumin reduces low density lipoprotein and very low-density lipoprotein significantly in plasma and total cholesterol level in liver with an increment of $\alpha$-tocopherol level in rat plasma. It is suggested that in vivo interaction between curcumin and $\alpha$-tocopherol that may increase the bio availability of vitamin E and decrease cholesterol levels (Kamal-Eldin et al., 2000).

Risks of type 2 diabetes can be minimized by the regular consumption of turmeric. It lowers post prandial blood glucose levels by increasing the glucose metabolism (Nisar et al., 2015). It has been proven that both turmeric and curcumin can reduce blood glucose levels in alloxan induced diabetics rats (Arun and Nalini, 2002). They also can effectively reduce advanced glycation end products induced complication in diabetic mellitus (Sajithlal et al., 1998).

Investigations on immunostimulant properties of Curcuma longa on splenic macrophages in male albino mice that were $\mathrm{CCl}_{4}$ intoxicated, it is suggested that turmeric boost immunity by changing the cytokine milieu of the immunosuppressed macrophages, thereby regulating their functional status (Chakraborty and Sengupta, 2012).

\section{Pharmacological activity of Ginger}

\subsection{Antibacterial activity}

It has been proved that methanol and $\mathrm{n}$-hexane extracts of ginger have an antibacterial activity against Klebsiella pneumonia, Escherichia coli, Shigella dysenteriae and Salmonella enterica (Iotsor et al., 2019). It is reported that gingerol is the active inhibitor of Mycobacterium avium and Mycobacterium tuberculosis (Hiserodt et al., 1998).

*Correspondence: madhura@sci.sjp.ac.lk

Tel: +94716255690

(C) University of Sri Jayewardenepura 
Ginger has antibacterial effect against Gram positive bacteria; Bacillus cereus and Listeria monocytogenes (Teimoory et al., 2013). Another research has revealed that ethanol and n-hexane extract of ginger clearly exhibited antibacterial activities of anaerobic Gram-negative bacteria, Porphyromonas gingivalis, Prevotella intermedia and Porphyromonas endodontalis; causing periodontal diseases at a minimum inhibitory concentration range of 6-30 $\mu \mathrm{g} / \mathrm{ml}$ (Park et al., 2008). Ginger extract exhibited potent antibacterial activity against Streptococcus pyogenes, Streptococcus pneumonia, Staphylococcus aureus and Haemophilus influenza (Akoachere et al., 2002), Pseudomonas aeruginosa, Escherichia coli and Salmonella typhimurium (Jagetia et al., 2003).

\subsection{Antifungal activity}

According to a study done to compare antifungal properties of garlic, ginger and lime, ginger has shown highest antifungal activity against Aspergillus flavus, Aspergillus niger and Cladosporium herbarum (Tagoe et al., 2009). Compounds like 6-, 8-, 10-gingerols and 6-gingerdiols which have been isolated form Zingiber officinale have shown antifungal activity against Cryptococcus neoformans, Wangiella dermatitidis, Aspergillus fumigatus, Microsporum gypseum, Pseudallescheria boydii and Trichophyton mentagrophytes at concentrations below $1 \mathrm{mg} / \mathrm{ml}$ (Ficker et al., 2003).

Table 3: Minimum Inhibitory Concentration (MIC) values of some bacteria and fungi inhibited by ginger.

\begin{tabular}{llll}
\hline Bacteria/fungi & $\begin{array}{l}\text { Antimicrobial } \\
\text { Substance }\end{array}$ & $\begin{array}{l}\text { Minimum inhibitory } \\
\text { concentration (MIC) }\end{array}$ & Reference \\
\hline Escherichia coli & Methanol extract & $125 \mu \mathrm{g} / \mathrm{ml}$ & (Hossain et al., 2020) \\
Salmonella typhi & Methanol extract & $62.5 \mu \mathrm{g} / \mathrm{ml}$ & (Hossain et al., 2020) \\
Staphylococcus aureus & Methanol extract & $31.2 \mu \mathrm{g} / \mathrm{ml}$ & (Hossain et al., 2020) \\
Enterococcus faecalis & Methanol extract & $62.5 \mu \mathrm{g} / \mathrm{ml}$ & (Hossain et al., 2020) \\
Helicobactor pylori & Methanol extract & $6.25-50 \mu \mathrm{g} / \mathrm{ml}$ & (Mahady et al., 2003) \\
Acinetobacter baumannii & Ethanol extract & $20 \mathrm{mg} / \mathrm{ml}$ & (Aghazadeh et al., 2016) \\
Proteus spp & Ethanol extract & $70.2 \mathrm{O \mu g} / \mathrm{ml}$ & (Karuppiah and Rajaram, \\
& & & 2012). \\
Candida albicans & Ethanol extract & $10 \mathrm{mg} / \mathrm{ml}$ & (Aghazadeh et al., 2016) \\
Candida krusei & Ethanol extract & $5 \mathrm{mg} / \mathrm{ml}$ & (Aghazadeh et al., 2016) \\
\hline
\end{tabular}

\subsection{Antifungal activity}

According to a study on antiviral activity of dried rhizomes of ginger in the plaque reduction test, $\beta$-sesquiphellandrene of ginger has antiviral activity against rhinoviruses which cause common cold (Denyer et al., 1994). Aqueous extract of ginger has shown antiviral activity against Feline calicivirus, a surrogate for human Norovirus when in gastro-intestinal tract infections due to foodborne reasons (Aboubakr et al., 2016). Allicin in ginger has exhibited antiviral activity against Influenza A (H1N1) which causes swine flu (Sahoo et al., 2016). 
Table 4: Antiviral activity of ginger.

\begin{tabular}{|c|c|c|c|}
\hline Virus & $\begin{array}{l}\text { Antiviral } \\
\text { substance }\end{array}$ & $\begin{array}{l}\text { Mode of action / mechanism of } \\
\text { inhibition }\end{array}$ & References \\
\hline $\begin{array}{l}\text { Human } \\
\text { respiratory } \\
\text { syncytial virus } \\
\text { (HRSV) }\end{array}$ & Fresh ginger & $\begin{array}{l}\text { Inhibit HRSV-induced plaque } \\
\text { generation in respiratory } \\
\text { mucosal cell layers. High } \\
\text { concentration of ginger can } \\
\text { trigger mucosal cells to secrete } \\
\text { IFN- } \beta \text { counteracts viral } \\
\text { infections by hindering viral } \\
\text { attachment and internalization }\end{array}$ & (Chang et al., 2013) \\
\hline $\begin{array}{l}\text { Chikungunya } \\
\text { virus }\end{array}$ & Aqueous extract & $\begin{array}{l}\text { Hamper the chikungunya } \\
\text { replication }\end{array}$ & (Kaushik et al., 2020) \\
\hline Hepatitis C & $\begin{array}{l}\text { Lyophilized juice } \\
\text { extract }\end{array}$ & $\begin{array}{l}\text { Inhibit viral replication within } \\
\text { the Hepatitis C virus. Affects } \\
\text { viral RNA in infected Hep G2 } \\
\text { cells. }\end{array}$ & (El-Wahab et al., 2009) \\
\hline $\begin{array}{l}\text { Herpes simplex } \\
\text { virus type } 1 \\
\text { (HSV-1) }\end{array}$ & Essential oil & $\begin{array}{l}\text { Interfere with virion envelope } \\
\text { structures which are necessary } \\
\text { for adsorption to or entry into } \\
\text { host cells or might dissolute the } \\
\text { HSV envelope }\end{array}$ & (Schnitzler et al., 2007) \\
\hline $\begin{array}{l}\text { Herpes simplex } \\
\text { virus type } 2 \\
\text { (HSV-2) }\end{array}$ & Essential oil & $\begin{array}{l}\text { Interact with the viral envelop } \\
\text { before adsorption }\end{array}$ & (Koch et al., 2008). \\
\hline Influenza A virus & $\begin{array}{l}\text { Honey, ginger and } \\
\text { garlic mixture }\end{array}$ & $\begin{array}{l}\text { Disrupt the disulphide bonds } \\
\text { between } \mathrm{H} 1 \text { and } \mathrm{H} 2 \text { that are } \\
\text { essential for the functional } \\
\text { integrity of Haemagglutination }\end{array}$ & (Vahed et al., 2016). \\
\hline
\end{tabular}

\subsection{Anti-parasitic effect}

Ginger extract shows effects against Toxoplasma gondii through inactivation of apoptotic proteins in infected host cells via the direct inhibition of Toxoplasma gondii and also ginger extract has antiparasitic activities that inhibit secretion of inflammatory cytokine (Choi et al., 2013). Dichloromethane extract of ginger and cinnamon has shown inhibitory activity against Giardia lamblia by reducing faecal cyst and trophozoites count of Giardia lamblia (Mahmoud et al., 2014).

According to a study done to investigate inhibitory activity of ginger and garlic extract on infected mice with Blastocystic spp, ginger has shown anti-protozoan activity against Blastocytis (Abdel-Hafeez

*Correspondence: madhura@sci.sjp.ac.lk

Tel: +94 716255690

(C) University of Sri Jayewardenepura 
et al., 2015). Methanol extract of ginger has exhibited antitrypanosomal effect in Trypanosoma brucei bruce i infected Wistar mice (Kobo et al, 2014).

Table 4: Anti-parasitic activity of ginger.

\begin{tabular}{|c|c|c|c|}
\hline Parasite & $\begin{array}{l}\text { Antiparasitic } \\
\text { substance }\end{array}$ & $\begin{array}{l}\text { Disease caused by } \\
\text { parasite }\end{array}$ & Reference \\
\hline $\begin{array}{l}\text { Angiostrongylus } \\
\text { cantonensis }\end{array}$ & $\begin{array}{l}\text { 6-gingerol, 6-shogaol, } \\
\text { 10-shogaol, 10- } \\
\text { gingerol and } \\
\text { hexahydrocurcumin }\end{array}$ & $\begin{array}{l}\text { Angiostrongyliasis, a } \\
\text { major cause of } \\
\text { eosinophilic } \\
\text { meningitis }\end{array}$ & (Lin et al., 2010) \\
\hline Anisakis simplex & $\begin{array}{l}\text { 10-shogaol, 6-shogaol, } \\
\text { 10-gingerol and 6- } \\
\text { gingerol }\end{array}$ & Anisakiasis & (Lin et al., 2010) \\
\hline Toxocara canis & Ethanol extract & Toxocariasis & (El-Sayed, 2017) \\
\hline Dirofilaria immitis & Aqueous extract & Heartworm disease & (Merawin et al., 2010) \\
\hline Hymenolepis nana & $\begin{array}{l}\text { 10-shogaol and 10- } \\
\text { gingerol }\end{array}$ & Hymenolepiasis & (Lin et al., 2014) \\
\hline $\begin{array}{l}\text { Echinococcus } \\
\text { granulosus }\end{array}$ & 6-gingerol & cystic echinococcosis & $\begin{array}{ll}\text { (Amri and } & \text { Touil- } \\
\text { Boukoffa, 2016) } & \end{array}$ \\
\hline Toxoplasma gondii & Methanol extract & Toxoplasmosis & (Choi et al., 2013) \\
\hline Giardia lamblia & $\begin{array}{l}\text { Dichloromethane } \\
\text { extract }\end{array}$ & Giardiasis & (Mahmoud et al., 2014) \\
\hline
\end{tabular}

\subsection{Antioxidant activity}

There are about 40 antioxidant compounds including $\beta$-carotene, ascorbic acid, terpenoids, alkaloids and phenols such as flavonoids and flavones in ginger (Kikuzaki and Nakatani, 1996). Therefore, it is believed that ginger can protect human body against cancer, heart disease and arteriosclerosis. This is because antioxidants can minimize the oxidation stress and they have the ability to counteract damages caused by free radicals in tissues (Mekuriya and Mekibib, 2018).

A study has indicated that ginger oil can inhibit the oxygen radicals through the inhibition of lipid peroxidation, scavenging of superoxide and hydroxyl radical in vitro. It also can remove superoxide radicals generated in vivo in mice peritoneal macrophages. The antioxidant property of ginger oil may be due to the mixture of different functional group compounds, polarity and chemical behaviour that produces either synergistic or antagonistic effect on antioxidant activity (Jeena et al., 2013).

\subsection{Anti-inflammatory and analgesic actions}

Ginger has been identified to have anti-inflammatory properties. It has been discovered that ginger inhibits the induction of numerous genes encoding chemokines, cytokines and inducible enzyme cyclooxygenase-2, thus it regulates biochemical pathways activated in chronic inflammation (Mishra et al., 2012). According to a study done to evaluate the effects of the volatile oil of ginger on the immune response in vitro and in vivo in mice, volatile oil of ginger significantly inhibits $\mathrm{T}$ lymphocyte proliferation, decrease the amount of $\mathrm{T}$ lymphocytes and $\mathrm{T}$ helper cells in a manner that depends on concentration. However, it increases the percentage of $\mathrm{T}$ suppressor cells to the total $\mathrm{T}$ lymphocytes in the 
mice in-vitro and oral administration of volatile ginger oil weaken the delayed hypersensitivity response to 2,4-dinotro-1-fluorobenzene in the sensitized mice in-vivo. Therefore, it is suggested that volatile oil of ginger enhance both cell - mediated immune response as well as nonspecific proliferation of Tlymphocyte while providing beneficial impacts in some clinical conditions like autoimmune diseases and chronic inflammation (Zhou et al., 2006).

\subsection{Gastro-protective effect}

Ginger is the most proven plant based remedy for gastric ulcers and is a magnificent gastroprotectant which increases secretion of mucin, reduces the numbers of small proteins and inflammatory cytokines, which signals the human immune mechanism to initiate an inflammatory response at the stomach. According to a study on impacts by ginger against gastric damage induced by aspirin in rats, ginger powder ameliorates the aspirin-induced increases in mucosal activity of the inducible form of interleukin (IL)-1 $\beta$ levels. NO synthase (iNOS) and plasma tumor necrosis factor (TNF)- $\alpha$. Hence, ginger powder avoids the aspirin induced gastric ulcer generation by decreasing mucosal iNOS activity and the plasma levels of inflammatory cytokines. However, it does not impact on gastric juice/acid production or $\mathrm{PGE}_{2}$ content in mucosa (Wang et al., 2011). Active compounds of ginger are reported to induce digestion, absorption, relieve flatulence and constipation by improving muscular activity in the gastro-intestinal tract (Ghosh et al., 2011).

\subsection{Cholesterol-lowering or Lipolytic-lowering properties}

Ginger has lipolytic or cholesterol lowering property. A study conducted to determine the ex-vivo effect of standardized ginger extract on the development of atherosclerosis in apolipoprotein E-deficient $\left(\mathrm{E}^{0}\right)$ mice, demonstrated that dietary intake of ginger extract by $\mathrm{E}^{0}$ mice significantly reduce the formation of aortic atherosclerotic lesions while decreasing plasma and LDL cholesterol levels. According to the results it can be stated that consumption of ginger extract can attenuate the development of atherosclerosis as it is associated with reduced macrophage-mediated oxidation of LDL, lower uptake of oxidized LDL by macrophages, low oxidative state of LDL and reduced LDL aggregation. As a result, can reduce accumulation of cellular cholesterol and formation of foam cell, which is hallmark of early atherosclerosis (Fuhrman et al., 2000).

\subsection{Anti-tumor activity}

Fribroblast Growth Factor (FGF) as well as the Vascular Endothelial Growth Factor (VEGF) play a central role in the formation and the progression of tumors. In order to prevent tumor development, inhibition of VEGF and FGF is very important. Ginger shows strong impact on reducing tumor development via up-regulation of the tumor suppressor gene, inactivation of VEGF pathways and induction of apoptosis (Kim et al., 2005).

\subsection{Anti-diabetic activity}

Aqueous ginger extract has remarkably decreased blood cholesterol, glucose and triacylglycerol levels in diabetes induced rats. Also, it demonstrated that raw extract of ginger fully eliminated the proteinuria caused by diabetic nephropathy. Thus, it can be suggested that treatment using ginger

*Correspondence: madhura@sci.sjp.ac.lk

Tel: +94716255690

(C) University of Sri Jayewardenepura 
facilitated in curing the nephropathy resulting from STZ-induction in diabetics. According to that study the hypoglycaemic activity of ginger is due to effects involving serotonin receptors resulting an increase in pancreatic beta cells' secretion of insulin or release of bound insulin (Al-Amin et al., 2006).

\subsection{Other health benefits}

Fresh ginger is used as remedies for cold induced diseases, cough, asthma, dyspepsia, colic heart palpitation, nausea, swelling, rheumatism and loss of appetite and it has been used as a treatment for cough and asthma when mixed with little amount of honey and lemon juice (Karuppiah and Rajaram, 2012). Ginger has health promoting properties against cancer including skin, breast, gastric, liver, oral, brain, pancreatic, prostate, colon, renal, ovarian and cervical cancers, cardiovascular diseases, vomiting, diabetes mellitus and degenerative health disorders such as arthritis, rheumatism and Alzheimer's disease (Lee et al., 2019). Ginger has been used to treat heartburn, morning sickness, colic, stomach upset, dyspepsia and bloating (Mowrey and Clayson, 1982) and also it is good for muscle soreness, low back pain, chest pain and menstrual pain (Kaushik et al., 2020).

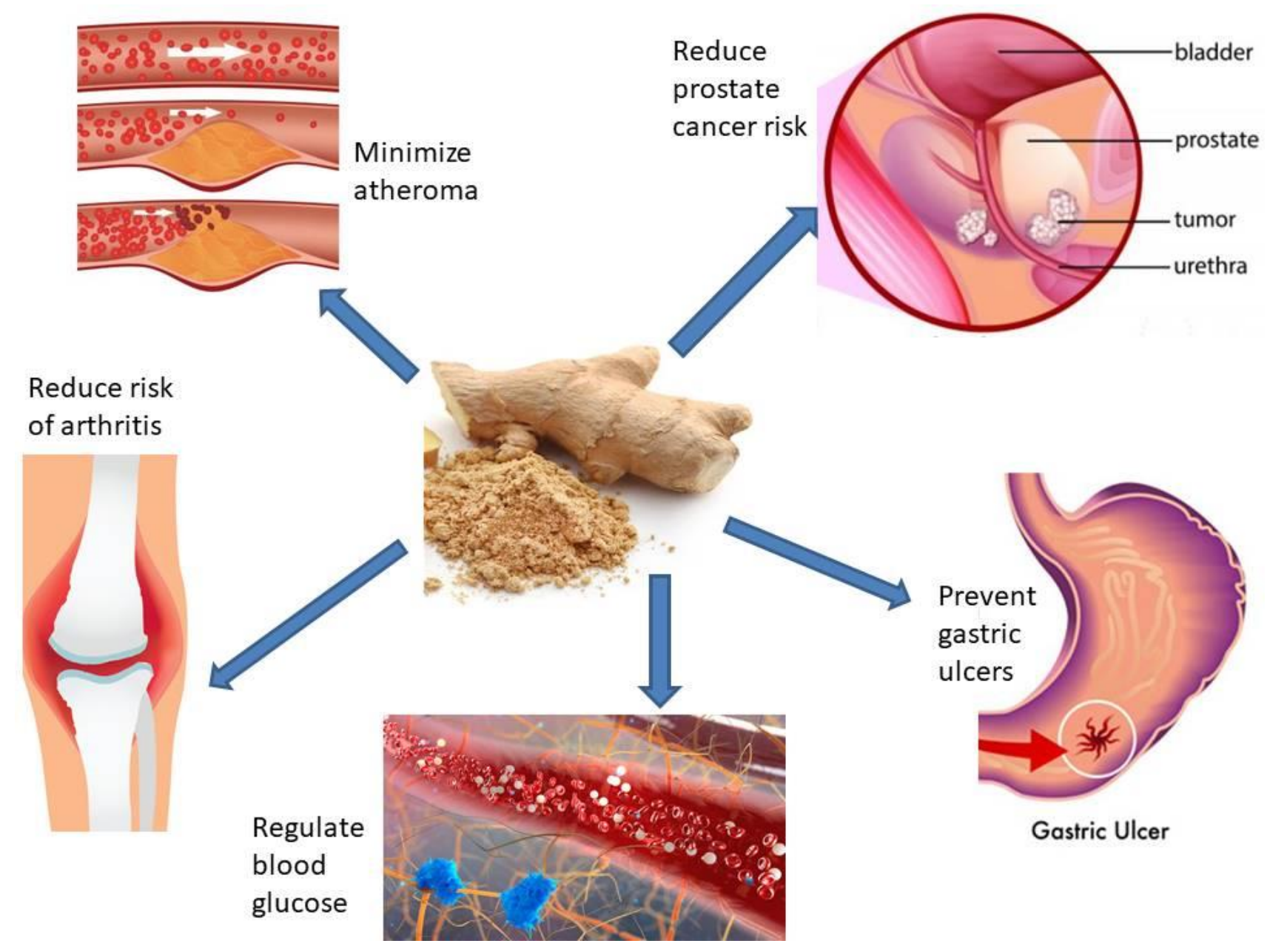

Figure 3. Multiple health protective properties of ginger. 
A study was designed for management of prostate cancer. In-vivo and in-vitro anticancer activity of ginger extract have elicited significant death introductory and growth inhibitory effects in a broad spectrum of prostate cancer cells. It has been confirmed that ginger extract modulated cell-cycle, perturbed cell-cycle progression, apoptosis regulatory molecules, impaired reproductive capacity and induced a caspase-driven, mitochondrial mediated apoptosis in prostate cancer cells of humans (Karna et al., 2012).

Ginger has an anti-arthritic effect. Ginger extract can prevent both joint inflammation and destruction. It is believed that anti-arthritic effect of ginger involves additive and synergistic effects of multiple components including both gingerols and non-gingerol compounds (Funk et al., 2009). A study has shown that ginger powder at dose of 500-600 mg, administered for 3-4 days with gaps of four hours can minimize occurrence of migraine attacks (Mustafa and Srivastava, 1990).

A study has been conducted to identify the positive effects of an aqueous ginger extract on human immune system and antibodies, hematology and thyroid hormones in male smokers as well as nonsmokers. Before consumption, smokers elicited higher Red Blood Cell (RBC) count and lower neutrophil count compared to the non-smoking group. After consuming the ginger extract lymphocyte count and haemoglobin concentration of smokers has significantly increased. Therefore, ginger consumption can be beneficial for smokers as they have less amount of haemoglobin molecules available for binding oxygen due to cigarette smoke and it will be beneficial for smokers with anaemia. After consumption of ginger extract eosinophil count and IgM concentration of non-smokers have increased and it leads to a stronger response by antibodies or humoral immunity against infectious pathogens. Also thyroid gland function has been enhanced by ginger extract in both smokers and non-smokers as TSH were decreased after consumption of ginger extract (Mahassni and Bukhari, 2019).

\section{Conclusion}

Curcuma longa (Turmeric) and Zingiber officinale (Ginger) are medicinal spice plants from Zingiberaceae family, which have been identified from several studies to contain active ingredients responsible for therapeutic pharmacological effects associated with a feasible medical value when using as spices. Although future studies are necessary, the great potential of turmeric and ginger in food processing is supported by isolation the active ingredients and intercalate it with food applications and/or by nanotechnology to upgrade the effects of active ingredients on human health.

\section{References}

Abdel-Hafeez, E.H., Ahmad, A.K., Kamal, A.M., Abdellatif, M.Z., Abdelgelil, N.H., 2015. In vivo antiprotozoan effects of garlic (Allium sativum) and ginger (Zingiber officinale) extracts on experimentally infected mice with Blastocystis spp. Parasitology research, 114:3439-3444.

Aboubakr, H.A., Nauertz, A., Luong, N.T., Agrawal, S., El-Sohaimy, S.A.A., Youssef, M.M., Goyal, S.M., 2016. In Vitro Antiviral Activity of Clove and Ginger Aqueous Extracts against Feline calicivirus, a Surrogate for Human Norovirus. Journal of food protection, 79:1001-1012.

Aghazadeh, M., Bialyaei, A.Z., Aghazadeh, M., Kabiri, F., Saliani, N., Yousefi, M., Eslami, H., Kafil, H.S., 2016. Survey of the antibiofilm and antimicrobial effects of Zingiber officinale (In vitro study). Jundishapur Journal of Microbiology, 9:1-6.

*Correspondence: madhura@sci.sjp.ac.lk

Tel: +94 716255690

(C) University of Sri Jayewardenepura 
Al-Amin, Z.M., Thomson, M., Al-Qattan, K.K., Peltonen-Shalaby, R., Ali, M., 2006. Anti-diabetic and hypolipidaemic properties of ginger ( Zingiber officinale) in streptozotocin-induced diabetic rats. British Journal of Nutrition, 96:660-666.

Ali, B.H., Blunden, G., Tanira, M.O., Nemmar, A., 2008. Some phytochemical , pharmacological and toxicological properties of ginger (Zingiber officinale Roscoe): A review of recent research. 46:409420.

Aly, M.M., Gumgumjee, N. M., 2011. Antimicrobial efficacy of Rheum palmatum, Curcuma longa and Alpinia officinarum extracts against some pathogenic microorganisms. African Journal of Biotechnology, 10:1258-1263.

Amri, M., Touil-Boukoffa, C., 2016. In vitro anti-hydatic and immunomodulatory effects of ginger and [6]-gingerol. Asian Pacific Journal of Tropical Medicine, 9:749-756.

Aplsarlyakul, A., Vanittanakom, N., Buddhasukh, D., 1995. Antifungal activity of turmeric oil extracted from Curcuma longa (Zingiberaceae). Journal of Ethno Pharmacology, 49:163-169.

Arun, N., Nalini, N., 2002. Efficacy of turmeric on blood sugar and polyol pathway in diabetic albino rats. Plant Foods for Human Nutrition, 57:41-52.

Arutselvi, R., Balasaravanan, T., Ponmurugan, P., Suresh, P.R., 2012. Comparative Studies of Anti-microbial Activity of Turmeric and Selected Medicinal Plant Leaf Extracts Used in Indian Traditional Medicine. Journal of herbs, spices \& medicinal plants, 18(3), 231-239.

Barthelemy, S., Vergnes, L., Moynier, M., Guyot, D., Labidalle, S., Bahraoui, E.S., 1998. Curcumin and curcumin derivatives inhibit Tat-mediated transactivation of type 1 human immunodeficiency virus long terminal repeat. Res. Virol, 149:43-52.

Bose, S., Panda, A.K., Mukherjee, S., Sa, G., 2015. Curcumin and tumor immune-editing: Resurrecting the immune system. Cell Division, 10:6-8.

Chakraborty, B., Sengupta, M., 2012. Boosting of nonspecific host response by aromatic spices turmeric and ginger in immunocompromised mice. Cellular Immunology, 280:92-100.

Chan, A.T., Manson, J., Albert, C., Chae, C., Rexrode, K., Curhan, G., Rimm, E., Willet, W., Fuchs, C., 2006. Nonsteroidal antiinflammatory drugs, acetaminophen, and the risk of cardiovascular events. Circulation, 113:1578-1587.

Chang, J.S., Wang, K.C., Yeh, C.F., Shieh, D.E., Chiang, L.C., 2013. Fresh ginger (Zingiber officinale) has anti-viral activity against human respiratory syncytial virus in human respiratory tract cell lines. Journal of Ethnopharmacology, 145:146-151.

Chattopadhyay, I., Biswas, K., Bandyopadhyay, U., Banerjee, R.K., 2004. Turmeric and curcumin: Biological actions and medicinal applications. Current Science, 87:44-53.

Chen, D., Shien, J., Tiley, L., Chiou, S., Wang, S., Change, T., Lee, Y., Chan, K., Hsu, W., 2010. Curcumin inhibits influenza virus infection and haemagglutination activity. Food Chemistry, 119:13461351.

Chiang, L.J., Zhang, L.J., Dezube, B.J., Crumpacker, C.S., Pardee, A.B., 1993. Three inhibitors of type 1 human immunodeficiency virus long terminal repeat-directed gene expression and virus replication. Proc. Natl. Acad Sci. USA, 90:1839-1842.

Choi, W.H., Jiang, M.H., Chu, J.P., 2013. Antiparasitic effects of Zingiber officinale (ginger) extract against Toxoplasma gondii. Journal of Applied Biomedicine, 11:15-26.

Chowdhury, H., Walia, S., Saxena, V.S., 2000. Isolation, characterization and insect growth inhibitory activity of major turmeric constituents and their derivatives against Schistocerca gregaria (Forsk) and Dysdercus koenigii (Walk). Pest Management Science: formerly Pesticide Science, 56(12), 1086-1092..

20 
Chrubasik, S., Pittler, M.H., Roufogalis, B.D., 2006. Zingiberis rhizoma : A comprehensive review on the ginger effect and efficacy profiles. Phytomedian, 12:684-701.

Denyer, C.V., Jackson, P., Loakes, D.M., Ellis, M.R.., Young, D.A., 1994. Isolation of antirhinoviral sesquiterpenes from ginger (Zingiber officinale). Journal of natural products, 57:658-662.

Dutta, K., Ghosh, D., Basu, A., 2009. Curcumin Protects Neuronal Cells from Japanese Encephalitis Virus-Mediated Cell Death. Journal of Neuroimmune Pharmacology, 4(3), 328-337.

El-Sayed, N.M., 2017. Efficacy of Zingiber officinale ethanol extract on the viability, embryogenesis and infectivity of Toxocara canis eggs. Journal of Parasitic Diseases, 41:1020-1027.

El-Wahab A.A., El-Adawi H., El-Demellawy M., 2009. In-vitro study of the antiviral activity of Zingiber officinale. Planta Med., 75.

Ficker, C., Smith, M.L., Akpagana, K., Gbeassor, M., Zhang, J., Durst, T., Assabgui, R., Arnason, J.T., 2003. Bioassay-Guided Isolation and Identification of Antifungal Compounds from Ginger. Phytotherapy research, 17:897-902.

Fuhrman, B., Rosenblat, M., Hayek, T., Coleman, R., Aviram, M., 2000. Ginger extract consumption reduces plasma cholesterol, inhibits LDL oxidation and attenuates development of atherosclerosis in atherosclerotic, apolipoprotein E-deficient mice. Journal of Nutrition, 130:1124-1131.

Funk, J.L., Frye, J.B., Oyarzo, J.N., Timmermann, B.N., 2009. Comparative effects of Two Gingerol-containing Zingiber officinale Extracts on Experimental Rheumatoid Arthritis. Journal of Natural Products, 72:403-407.

Gomes, D.C., Alegrio, L.V., de Lima, M.E., Leon, L.L., Araújo, C.A., 2002. Synthetic derivatives of curcumin and their activity against Leishmania amazonensis. Arzneimittelforschung, 52:120-124.

Ghosh, A.K., Banerjee, S., Mullick, H.I., Banerjee, J., 2011. Zingiber officinale: A natural gold. Int J Pharm Bio Sci, 2:283-294.

Guerra, A.M.S., Hoyos, C.G., Velasquez-Cock, J.A., Acosta, L.V., Rojo, P.G., Giraldo, A.M.V., Gallego, R.Z., 2020. The nanotech potential of turmeric (Curcuma longa L.) in food technology : A review. Critical Reviews in Food Science and Nutrition, 60:1842-1854.

Hergenhahn, M., Soto, U., Weninger, A., Polack, A., Hsu, C.H., Cheng, A.L., Rösl, F., 2002. The chemopreventive compound curcumin is an efficient inhibitor of Epstein-Barr virus BLZF1 transcription in Raji DR-LUC cells. Mol. Carcinogen, 33:137-145.

Hiserodt, R.D., Franzblau, S.G., Rosen, R.T., 1998. Isolation of 6-, 8-, and 10-gingerol from ginger rhizome by HPLC and preliminary evaluation of inhibition of Mycobacterium avium and Mycobacterium tuberculosis. J. Agric. Food Chem., 46:2504-2508.

Hossain, T., Hoque, S.A., Nasrinsultana, U., 2020. Evaluation of antimicrobial and cytotoxic activities of the extracts of Capsicum annuum and Zingiber officinale. ISOR Journal of Pharmacy and Biological Sciences, 15:27-33.

Iotsor, B.I., Izegohi, F., Oladoja, O.E., Raji, O.R., Yusuf, Z., Oyewole, O.A., 2019. Antimicrobial Activities of Garlic and Ginger Extracts on Some Clinical Isolates. The International Journal of Biotechnology, 8:59-65.

*Correspondence: madhura@sci.sjp.ac.lk

Tel: +94716255690

(C) University of Sri Jayewardenepura 
Jagetia, G.C., Baliga, M.S., Venkatesh, P., Ulloor, J.N., 2003. Influence of ginger rhizome (Zingiber officinale Rosc) on survival, glutathione and lipid peroxidation in mice after whole-body exposure to gamma radiation. Radiation research, 160:584-592.

Jayaprakasha, G.K., Negi, P.S., Anandharamakrishnan, C., Sakariah, K.K., 2001. Chemical composition of turmeric oil - a byproduct from turmeric oleorsin industry and its inhibitory activity against different fungi. Z. Naturforsch., 56:40-44.

Jeena, K., Liju, V.B., Kuttan, R., 2013. Antioxidant, anti-inflammatory and antinociceptive activities of essential oil from ginger. Indian Journal of Physiology and Pharmacology, 57:51-62.

Joe, B., Lokesh, B.R., 1994. Role of capsaicin, curcumin and dietary n - 3 fatty acids in lowering the generation of reactive oxygen species in rat peritoneal macrophages. Biochimica et Biophysica Acta, 1224:255-26.

Juglal, S., Govinden, R., Odhav, B., 2002. Spice oils for the control of co-occurring mycotoxinproducing fungi. Journal of Food Protection, 65:683-687.

Kamal-Eldin, A., Frank, J., Razdan, A., Tengblad, S., Basu, S., Vessby, B., 2000. Effects of dietary phenolic compounds on tocopherol, cholesterol, and fatty acids in rats. Lipids, 35:427-435.

Karna, P., Sharmeen, C., Gundala, S.R., Rida, P.C.G., Asif, G., Sharma, V., Gupta, M.V., Aneja, R., 2012. Benefits of whole ginger extract in prostate cancer. British Journal of Nutrition, 107:473-484.

Karuppiah, P., Rajaram, S., 2012. Antibacterial effect of Allium sativum cloves and Zingiber officinale rhizomes against multiple-drug resistant clinical pathogens. Asian Pacific Journal of Tropical Biomedicine, 597-601.

Kaushik, S., Jangra, G., Kundu, V., Yadav, J.P., Kaushik, S., 2020. Anti-viral activity of Zingiber officinale (Ginger) ingredients against the Chikungunya virus. VirusDisease. Springer India, 31:270-276.

Khattak, S., Saeed-ur-Rehman, Ullah, S.H., Ahmad, W., Ahmad, M., 2005. Biological effects of indigenous medicinal plants Curcuma longa and Alpinia galanga. Fitoterapia, 76:7-254.

Kikuzaki, H., Nakatani, N., 1996. Cyclic diarylheptanoids from rhizomes of Zingiber officinale. Phytochemistry, 43:273-277.

Kim, E.C., Min, J.K., Kim, T.Y., Lee, S.J., Yang, H.O.,Han, S., Kim, Y.M., 2005. [6]-Gingerol, a pungent ingredient of ginger, inhibits angiogenesis in vitro and in vivo. Biochemical and Biophysical Research Communications, 335:300-308.

Kim, H.J., Yoo, H.S., Kim, J.C., Park, C.S., Choi, M.S., Kim, M., Choi, H., Min, J.S., Kim, Y.S., Yoon, S.W., Ahn, J.K., 2009. Antiviral effect of Curcuma longa Linn extract against hepatitis B virus replication. Journal of Ethnopharmacology, 124:189-196.

Kim, K., Kim, K.H., Kim, H.Y., Cho, H.K., Sakamoto, N., Cheong, J., 2010. Curcumin inhibits hepatitis $\mathrm{C}$ virus replication via suppressing the Akt-SREBP-1 pathway. FEBS Letters. Federation of European Biochemical Societies, 584:707-712.

Kim, M.K., Choi G.J., Lee, H.S., 2003. Fungicidal property of Curcuma longa L. rhizome-derived curcumin against phytopathogenic fungi in a greenhouse. Journal of Agricultural and Food Chemistry, 51:1578-1581.

Kizhakkayil, J., Sasikumar, B., 2011. Diversity, characterization and utilization of ginger: a review, 9:464-477. Plant Genetic Resources, 9(3), 464-477.

Kobo, P.I., Erin, P.J., Suleiman, M.M., Aliyu, H., Tauheed, M., Muftau, S., Mamman, M., 2014. Antitrypanosomal effect of methanolic extract of Zingiber officinale (ginger) on Trypanosoma brucei brucei-infected Wistar mice. Veterinary World, 7:770-775.

Koch, C., Reichling, J., Schneele, J., Schnitzler, P., 2008. Inhibitory effect of essential oils against herpes simplex virus type 2. Phytomedicine, 15:71-78. 
Koide, T., Nose, M., Ogihara, Y., Yabu, Y., Ohta, N., 2002. Leishmanicidal effect of curcumin in vitro. Biological \& pharmaceutical bulletin, 25:131-133.

Krishnaswamy, K., Goud, V.K., Sesikeran B., Mukundan, M.A., Krishna, T.P., 1998. Retardation of experimental tumorigenesis and reduction in DNA adducts by turmeric and curcumin. Nutrition and Cancer, 30:163-166.

Kumari, N., Kulkami, A.A., Lin, X., McLean, C., Ammosova, T., Ivanov, A., Hipolito, M., Nekhai, S., Nwulia, E., 2015. Inhibition of HIV-1 by curcumin A, a novel curcumin analog. Drug Design, Development and Theerapy, 9:5051-5060.

Lawhavinit, O.A., Kongkathip, N., Kongkathip, B., 2010. Antimicrobial activity of curcuminoids from Curcuma Longa L. on pathogenic bacteria of shrimp and chicken. Kasetsart Journal - Natural Science, 44:364-371.

Lee, J.S., Kim, B., Kim, J.H., Jeong, M., Lim, S., Byun, S., 2019. Effect of differential thermal drying conditions on the immunomodulatory function of ginger. Journal of Microbiology and Biotechnology, 29:1053-1060.

Lin, R., Chen, C., Chung, L., Yen, C., 2010. Larvicidal activities of ginger (Zingiber officinale) against Angiostrongylus cantonensis. Acta Tropica. Elsevier B.V., 115:69-76.

Lin, R., Chen, C., Lee, J., Lu, C., Chung, L., Yen, C., 2010. Larvicidal constituents of Zingiber officinale (ginger) against Anisakis simplex. Planta medica, 76:1852-1858.

Lin, R., Chen, C., Lu, C., Ma, Y., Chung, L., Wang, J., Lee, J., Yen, C., 2014. Anthelmintic constituents from ginger (Zingiber officinale) against Hymenolepis nana. Acta Trop, 140:50-60.

Mahady, G.B., Pendland, S.L., Yun, G., Lu, Z.Z., 2002. Turmeric (Curcuma longa) and curcumin inhibit the growth of Helicobacter pylori, a group 1 carcinogen', Anticancer Research, 22:81-4179.

Mahady, G.B., Pendland, S.L., Yun, G.S., Lu, Z.Z., Stoia, A., 2003. Ginger (Zingiber officinale Roscoe) and the Gingerols Inhibit the Growth of Cag A+ Strains of Helicobacter pylori', Anticancer Research, 23:3699-3702.

Mahakunakorn, P., Tohda M., Murakami, Y., Matsumoto, K., Watanabe, H., Vajaragupta, O., 2003. Cytoprotective and cytotoxic effects of curcumin: Dual action on $\mathrm{H}_{2} \mathrm{O}_{2}$-induced oxidative cell damage in NG108-15 cells. Biological and Pharmaceutical Bulletin, 26:725-728.

Mahassni, S.H., Bukhari, O.A., 2019. Beneficial effects of an aqueous ginger extract on the immune system cells and antibodies, hematology, and thyroid hormones in male smokers and nonsmokers. Journal of Nutrition and Intermediary Metabolism. Elsevier, 15:10-17.

Mahmoud, A., Attia, R., Said, S., Ibraheim, Z., 2014. Ginger and cinnamon: Can this household remedy treat giardiasis? Parasitological and histopathological studies. Iranian Journal of Parasitology, 9:530-540.

Martins, C.V.B., Silva, D.L., Neres, A.T.M., Magalhaes, T.F.F., Watanabe, G.A., Modolo, L.V., Sabino, A.A., de Fatima, A., de Resende, M.A., 2009. Curcumin as a promising antifungal of clinical interest. Journal of Antimicrobial Chemotherapy, 63:337-339.

Mazumder, A., Raghavan, K., Weinstein, J., Kohn, K.W., Pommier, Y., 1995. Inhibition of human immunodeficiency virus type-1 integrase by curcumin. Biochemical Pharmacology, 49:1165-1170.

Mekuriya, W., Mekibib, B., 2018. Review on the Medicinal Values of Ginger for Human and Animal Ailments. Journal of Veterinary Science \& Technology, 09:9-12.

*Correspondence: madhura@ sci.sjp.ac.lk

Tel: +94 716255690

(C) University of Sri Jayewardenepura 
Merawin, L.T., Arifah, A.K., Sani, R.A., Somchit, M.N., Zuraini, A., Ganabadi, S., Zakaria, Z.A., 2010. Screening of microfilaricidal effects of plant extracts against Dirofilaria immitis. Research in Veterinary Science. Elsevier Ltd, 88:142-147.

Mishra, R.K., Kumar, A., Kumar, A., 2012. Pharmacological Activity of Zingiber officinale. International Journal of Pharmaceutical and Chemical Sciences, 1:1073-1078.

Moghadamtousi, S.Z., Kadir, H.A., Hassandarvish, P., Tajik, H., Abubakar, S., Zandi, K., 2014. A review on antibacterial, antiviral, and antifungal activity of curcumin. BioMed Research International, 112. 319:655-657.

Mowrey, D.B., Clayson, D.E., 1982. Motion Sickness, Ginger, and Psychophysics. The Lancet,

Mun, S., Joung, D., Kim, Y., Kang, O., Kim, S., Seo, Y., Kim, Y., Lee, D., Shin, D., Kweon, K., Kwon, D., 2013. Synergistic antibacterial effect of curcumin against methicillin-resistant Staphylococcus aureus. Phytomedicine, 20:714-718.

Mustafa, T., Srivastava, K.C., 1990. Ginger (Zingiber officinale) in migraine headache. Journal of Ethnopharmacology, 29:267-273.

Niamsa, N., Sittiwet, C., 2009. Antimicrobial Activity of Curcuma longa Aqueous Extract. Journal of Pharmacology and Toxicology, 4:173-177.

Navadagi, S.B., 2005. Gutkha in Oral Submucous Fibrosis and Effect of Turmeric on Osmf - a Histopathological Study in Experimental Animals. (Doctoral dissertation).

Negi, P.S., Jayaprakasha, G.K., Rao, L.J.M., Sakariah, K.K., 1999. Antibacterial Activity of Turmeric Oil: A Byproduct from Curcumin Manufacture. Journal of agricultural and food chemistry, 47(10), 4297-4300.

Nisar, T., Iqbal, M., Raza, A., Safdar, M., Iftikhar, F., Waheed, M., 2015. Turmeric: A Promising Spice for Phytochemical and Antimicrobial Activities. American-Eurasian J. Agric. \& Environ. Sci., 15:1278-1288.

Paramasivam, S., Thangaradjou, T., Kannan, L., 2007. Effect of natural preservatives on the growth of histamine-producing bacteria. J Environ Biol., 28:4-271.

Park, M., Bae, J., Lee, D.S., 2008. Antibacterial activity of [10]-gingerol and [12]-gingerol isolated from ginger rhizome against periodontal bacteria. Phytotherapy research PTR, 22:1446-1449.

Phan, T.T., See, P., Lee, S.T., Chan, S.Y., 2001. Protective effects of curcumin against oxidative damage on skin cells in vitro: its implication for wound healing. J Trauma, 51:927-931.

Pope, T., Loupe, L.N., Pillai, P.B., Emmert, J.L., 2004. Growth performance and nitrogen excretion of broilers using a phase-feeding approach from twenty-one to sixty-three days of age. Poultry Science. Poultry Science Association Inc., 83:676-682.

Rai, D., Singh, J.K., Roy, N., Panda, D., 2008. Curcumin inhibits FtsZ assembly: an attractive mechanism for its antibacterial activity. Biochemical Journal, 410:147-155.

Rathaur, P., Raja, W., Ramteke, P.W., John, S.A., 2012. Turmeric: The golden spice of life. International Journal of Pharmaceutical and Chemical Sciences and Research, 3:1987-1994.

Revathy, S., Elumalai, S., Benny, M., Antony, B., 2011. Isolation , Purification and Identification of Curcuminoids from Turmeric (Curcuma longa L.) by Column Chromatography. Journal of Experimental sciences, 2(7).

Sachdeva, A., Sharma, A., Bhateja, S., 2018. Emerging Trends of Herbs and Spices in Dentistry. Biomedical Journal of Scientific \& Technical Research, 4:1-5. 
Sahoo, M., Jena, L., Rath, S.N., Kumar, S., 2016. Identification of Suitable Natural Inhibitor against Influenza A (H1N1) Neuraminidase Protein by Molecular Docking. Genomics \& Informatics, 14:96-103.

Sajithlal, G.B., Chithra, P., Chandrakasan, G., 1998. Effect of curcumin on the advanced glycation and cross-linking of collagen in diabetic rats. Biochemical Pharmacology, 56:1607-1614.

Schnitzler, P., Koch, C., Reichling, J., 2007. Susceptibility of drug-resistant clinical herpes simplex virus type 1 strains to essential oils of ginger, thyme, hyssop, and sandalwood. Antimicrobial Agents and Chemotherapy, 51:1859-1862.

Shakila, R.J., Vasundhara, T.S., Rao, D.V., 1996. Inhibitory effect of spices on in vitro histamine production and histidine decarboxylase activity of Morganella morganii and on the biogenic amine formation in mackerel stored at 30 degrees C. Z Lebensm Unters Forsch, 203:6-71.

Sharma, R.A., Gescher, A.J., Steward, W.P., 2005. Curcumin: The story so far. European Journal of Cancer, 41:1955-1968.

Si, X., Wang, Y., Wong, J., Zhang, J., Mcmanus, B.M., Luo, H., 2007. Dysregulation of the Ubiquitin-Proteasome System by Curcumin Suppresses Coxsackievirus B3 Replication. Journal of Virology, 81:3142-3150.

Singh, R.K., Rai, D., Yadav, D., Bhargava, A., Balzarini, J., Clercq, E. De., 2010. Synthesis, antibacterial and antiviral properties of curcumin bioconjugates bearing dipeptide, fatty acids and folic acid. European Journal of Medicinal Chemistry, 45:1078-1086.

Suruchi, Y., Pramod K.S., Md, A.A., 2016. Ginger medicinal uses and benefits. European Journal of Pharmaceutical and Medical Research, 3:127-135.

Suryanarayana, P., Krishnaswamy, K., Reddy, G.B., 2003. Effect of curcumin on galactoseinduced cataractogenesis in rats. Molecular vision, 9:223-230.

Tagoe, D.N.A., Baidoo, S.E., Dadzie, I., Kangah, V.G., Nyarko, H.D., 2009. A comparison of the antimicrobial (antifungal) properties of garlic, ginger and lime on Aspergillus flavus, Aspergillus niger and Cladosporium herbarum using organic and water base extraction methods. Internet Journal of Tropical Medicine, 7.

Tassou, C.C., 2006. Herbs, spices and gut health, Handbook of Herbs and Spices, 151-176.

Teimoory, H., Azizi, M., Najafi, M.F., Behzadi, A., Rezaei, M., 2013. Antibacterial activity of Myrtus communis L. and Zingiber officinale rose extracts against some Gram positive pathogens. Research Opinions in Animal \& Veterinary Sciences, 3:478-481.

Thiyagarajan, M., Sharma, S.S., 2004. Neuroprotective effect of curcumin in middle cerebral artery occlusion induced focal cerebral ischemia in rats. Life Sciences, 74:969-985.

Ungphaiboon, S., Supavita, T., Singchangchai, P., Sungkarak, S., Rattanasuwan, P., Itharat, A., 2005. Study on antioxidant and antimicrobial activities of turmeric clear liquid soap for wound treatment of HIV patients. Songklanakarin J. Sci. Technol., 27:569-578.

Vahed, H., Jafri, S.B., Jamil, N., 2016. Propagation of Influenza Virus in Lymphocytes Determine by Antiviral Effects of Honey, Ginger and Garlic Decoction. Journal of Antivirals \& Antiretrovirals, 08:12-19.

Wang, Z, Hasegawa, J., Wang, X., Matsuda, A., Tokuda, T., Miura, N., Watanabe, T., 2011. Protective effects of ginger against aspirin-induced gastric ulcers in rats. Yonago Acta Medica, 54:11-19.

*Correspondence: madhura@sci.sjp.ac.lk

Tel: +94716255690

(C) University of Sri Jayewardenepura 
Zadeh, J.B., Kor, N.M., 2014. Physiological and pharmaceutical effects of Ginger (Zingiber officinale Roscoe) as a valuable medicinal plant, European Journal of Experimental Biology, 4:87-90.

Zhou, H.L., Deng, Y.M., Xie, Q.M., 2006. The modulatory effects of the volatile oil of ginger on the cellular immune response in vitro and in vivo in mice. Journal of Ethnopharmacology, 105:301-305. 